\title{
Effects of gamma irradiation on instream leaf litter decomposition
}

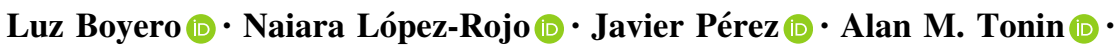 \\ Francisco Correa-Araneda (i) - Aaron Davis - Richard G. Pearson (i)
}

Received: 22 February 2021 / Revised: 13 September 2021/Accepted: 21 September 2021 / Published online: 4 October 2021

(C) The Author(s) 2021

\begin{abstract}
Leaf litter decomposition is a key process in stream ecosystems, the rates of which can vary with changes in litter quality or its colonization by microorganisms. Decomposition in streams is increasingly used to compare ecosystem functioning globally, often requiring the distribution of litter across countries. It is important to understand whether litter sterilization, which is required by some countries, can alter the rates of decomposition and associated processes. We examined whether litter sterilization
\end{abstract}

Handling editor: Marcelo S. Moretti

Supplementary Information The online version contains supplementary material available at https://doi.org/10.1007/ s10750-021-04703-w.

L. Boyero $(\bowtie) \cdot$ N. López-Rojo · J. Pérez

Department of Plant Biology and Ecology, Faculty of

Science and Technology, University of the Basque

Country (UPV/EHU), 48940 Leioa, Spain

e-mail: luz.boyero@ehu.eus

L. Boyero

IKERBASQUE, Basque Foundation for Science, Bilbao, Spain

\section{A. M. Tonin}

Department of Ecology, Institute of Biological Sciences, University of Brasília (UnB), Federal District, Brasília, Brazil with gamma irradiation ( $25 \mathrm{kGy}$ ) influenced decomposition rates, litter stoichiometry, and colonization by invertebrates after weeks of instream incubation within coarse-mesh and fine-mesh litterbags. We used nine plant species from three families that varied widely in litter chemistry but found mostly consistent responses, with no differences in decomposition rates or numbers of invertebrates found at the end of the incubation period. However, litter stoichiometry differed between irradiated and control litter, with greater nutrient losses (mostly phosphorus) in the former. Therefore, the effects of irradiation on litter chemistry should be taken into account in studies focused on stoichiometry but not necessarily in those focused on

\footnotetext{
F. Correa-Araneda

Unidad de Cambio Climático y Medio Ambiente, Instituto

Iberoamericano de Desarrollo Sostenible, Universidad Autónoma de Chile, Temuco, Chile
}

\author{
A. Davis · R. G. Pearson \\ TropWater, James Cook University, Townsville, \\ QLD, Australia \\ R. G. Pearson \\ College of Science and Engineering, James Cook \\ University, Townsville, QLD, Australia
}


decomposition rates, at least within the experimental timescale considered here.

Keywords Betulaceae $\cdot$ Breakdown $\cdot$ Coordinated networks $\cdot$ Fagaceae $\cdot$ Litterbags $\cdot$ Moraceae .

Sterilization $\cdot$ Stream ecosystems

\section{Introduction}

The process of leaf litter decomposition is considered a good indicator of stream ecosystem functioning and integrity (Gessner \& Chauvet, 2002; von Schiller et al., 2017) and is increasingly a focus of continental and global studies assessing the ecological consequences of climate change (Boyero et al., 2011), organic pollution (Woodward et al., 2012), land-use change (Ferreira et al., 2018), and biodiversity loss (Handa et al., 2014). These studies have been conducted through the coordinated work of multiple researchers and have generally involved incubating particular selected combinations of leaf litter in streams distributed worldwide, providing answers to globally relevant questions that are otherwise difficult to address (Boyero \& Pearson, 2017).

While coordinated global studies are successful in producing comparable results based on a single protocol (Boyero et al., 2021a), they are not without methodological challenges. For example, litter collected from a single location and distributed globally may risk the spread of infectious diseases such as fungal pathogens (Bjelke et al., 2016), which clearly should be avoided. In addition, the microorganisms contained in the litter could influence decomposition through, for example, home-field advantage mechanisms (Fanin et al., 2021). While an alternative to the collection and distribution of litter is the use of standard, non-natural substrates such as cotton strips (Tiegs et al., 2019), this is only possible when the focus is on microbial decomposition because these substrates are not processed by invertebrates, which are major agents of litter decomposition (Boyero et al., 2021c).

Different countries have their own restrictions when importing plant material, with some allowing import without any particular permit and others requiring that the plant material goes through some process of sterilization. One option for litter sterilization is subjecting it to high temperatures, but this procedure can alter decomposition rates through effects on nutrient leaching, microbial activity, and detritivore feeding (Correa-Araneda et al., 2020; Pérez et al., 2021). Another method, widely used in experiments examining microbially mediated decomposition and detritivore feeding preferences (e.g., Suberkropp et al., 1983; Gulis \& Suberkropp, 2003; Matulich \& Martiny, 2015), is subjecting litter to gamma irradiation. However, there has been no assessment of the potential effects of this sterilization method on litter decomposition rates and stoichiometry, which hinders comparisons across experiments. It is well known that gamma irradiation can alter soil chemical properties, particularly nitrogen (N) levels, although it has less effect than other sterilization methods such as autoclaving or fumigants (McNamara et al., 2003).

Here, we explored the effects of gamma irradiation (25 kGy) on litter decomposition and stoichiometry, as part of a global study ('DecoDiv') in which members of the GLoBE collaborative network (www.globenetwork.es) assessed the role of plant phylogenetic diversity on instream litter decomposition using 9 species from 3 families that were collected in different locations around the world (Boyero et al., $2021 b, c)$. Litter provided for use at different locations in Australia was required by import regulations to be subjected to gamma irradiation on entry. Here, we took advantage of this situation to examine the influence of irradiation on decomposition rates, nutrient stoichiometry, and colonization by invertebrates. We tested the null hypotheses that (i) the above variables do not differ between irradiated and non-irradiated litter, and that (ii) this lack of differences holds for plant families with different physical structure and chemical composition (López-Rojo et al., 2021).

\section{Material and methods}

\section{Leaf litter}

For the DecoDiv study, leaf litter of 9 plant species was collected from several locations worldwide: Alnus acuminata Kunth. (collected in Ecuador), Alnus glutinosa (L.) Gaertn. (Spain), Alnus incana (L.) Moench (Sweden), Ficus insipida Willd (Costa Rica), Ficus natalensis Hochst. (Kenya), Ficus dulciaria 
Dugand (Ecuador), Fagus sylvatica L. (France), Quercus prinus L. (United States), and Castanea sativa Mill. (Portugal). After being air-dried in local laboratories, litter of each species was stored in separate cartons, which were delivered to Spain, where they were collated and posted to the collaborators in 26 participating countries (Boyero et al., 2021c). We complied with the import requirements of each country, which in most cases involved completing import forms, but in Australia also required gamma irradiation ( $25 \mathrm{kGy})$ of the litter, following procedures described in https://www.agriculture.gov. au. All litter dispatched to Australia was irradiated (by Steritech, Dandenong, Victoria), following which one batch was returned to Spain to conduct the present experiment alongside a batch of material that had remained in Spain. The leaf litter remained within the original envelopes during transport to Australia and back to Spain, avoiding potential contact with microorganisms. No significant fragmentation of leaves caused by long-distance travel was observed.

Field and laboratory work

In Spain, we incubated the irradiated batch and the original (control) batch in a permanent, first-order stream located in the Agüera river catchment $(\mathrm{N}$ $43^{\circ} 12.745^{\prime} \mathrm{W} 3^{\circ} 16.256^{\prime} ; 350 \mathrm{~m}$ a.s.1.) between April 3 and 23,2018 . The climate in the region is temperate oceanic, with mean temperature of $14{ }^{\circ} \mathrm{C}$ and annual precipitation of $826 \mathrm{~mm}$. Riparian vegetation in the catchment comprises native mixed forest dominated by Quercus robur L., A. glutinosa, Corylus avellana L., and $C$. sativa. Mean $\pm \mathrm{SE}$ of stream wetted width during the incubation period was $1.31 \pm 0.10 \mathrm{~m}$; water depth $13.87 \pm 2.42 \mathrm{~cm}$; current velocity $0.24 \pm 0.05 \mathrm{~m} \mathrm{~s}^{-1}$; $\mathrm{pH} 7.34 \pm 0.06$; water temperature $10.39 \pm 0.95{ }^{\circ} \mathrm{C}$; conductivity $74.98 \pm 3.45 \mu \mathrm{S}$ $\mathrm{cm}^{-1}$; dissolved inorganic nitrogen (DIN) $528.86 \pm 46.37 \mu \mathrm{g} \mathrm{L}^{-1}$; and soluble reactive phosphorus (SRP) $8.69 \pm 3.83 \mu \mathrm{g} \mathrm{L}^{-1}$.

Litter was incubated in coarse-mesh $(5 \mathrm{~mm})$ and fine-mesh $(0.4 \mathrm{~mm})$ litterbags, which quantified total and microbial decomposition, respectively. There were 3 replicates per plant species, treatment (irradiated or control), and mesh type (108 litterbags in total), with each litterbag initially containing $c a .0 .85 \mathrm{~g}$ of litter, weighed precisely. Litterbags were anchored to the stream substrate using steel rods and stones and were left for 21 days, which was equivalent to 218 degree-days (dd). During the incubation period, the study site was visited weekly to ensure that litterbags were submerged and environmental conditions did not change greatly. Upon retrieval, litterbags were placed in individual zip-lock bags and transported to the laboratory on ice. The litter was rinsed with filtered stream water to remove attached sediment and invertebrates, oven-dried $\left(70{ }^{\circ} \mathrm{C}, 72 \mathrm{~h}\right)$, and weighed. A subsample was then weighed, incinerated $\left(500{ }^{\circ} \mathrm{C}\right.$, $4 \mathrm{~h}$ ), and re-weighed to estimate final ash-free dry mass (AFDM). Another subsample was used to determine final $\mathrm{N}$ content (using a Perkin Elmer series II CHNS/O elemental analyzer) and phosphorus (P) content (measured spectrophotometrically after autoclave-assisted extraction; APHA, 1998). Invertebrates were preserved in $70 \%$ ethanol until they were sorted under a stereo-microscope and identified to the lowest taxonomic level possible, counted, and assigned to feeding groups using available literature (e.g., Tachet et al., 2000). Initial litter stoichiometry was not measured on the experimental litter due to lack of material, but multiple litter traits of the studied species are provided in López-Rojo et al. (2021).

\section{Data analysis}

We examined the effect of litter irradiation on the following variables for litter incubated in coarse-mesh and fine-mesh litterbags: (1) decomposition, measured as proportional litter mass loss (LML), calculated as the difference between initial and final AFDM divided by initial AFDM (with initial AFDM previously corrected for leaching losses; López-Rojo et al., 2021); (2) nutrient stoichiometry, measured through carbon $(\mathrm{C}): \mathrm{N}, \mathrm{C}: \mathrm{P}$, and $\mathrm{N}: \mathrm{P}$ molar ratios at the end of the experiment; and (3) invertebrate colonization, measured through the abundance (number of individuals per $g$ of litter) and taxonomic richness (number of taxa per litterbag) of all invertebrates and of litterconsuming detritivores found at the end of the experiment (in coarse-mesh litterbags only).

All statistical analyses were performed in R 4.0.4. (R Core Team, 2020). We examined the null hypothesis of no differences between control and irradiated litter in the above variables using linear mixed-effect models ('lme' function, nlme $\mathrm{R}$ package; Pinheiro et al., 2020), with irradiation (control or irradiated), plant family (Betulaceae, Moraceae or Fagaceae), and 
their interaction as fixed factors, and species as a random factor. Models included the variance function structure varIdent, which allowed different variances for each irradiation or plant family treatment; the need for this term was identified in initial data exploration and confirmed by comparison of the Akaike Information Criterion (AIC) of models with and without this component. The normal distribution of residuals was inspected with plots and histograms, and no deviation was evident. When the interaction between treatment and family was significant, we used pairwise comparisons ('lsmeans' function, lsmeans $\mathrm{R}$ package, adjust $=$ 'Tukey') to identify differences between control and irradiated litter within families.

\section{Results}

We found no effects of irradiation on decomposition for any plant family in coarse-mesh and fine-mesh litterbags (Table 1). Litter decomposed by $28 \%$ on average (i.e., $1.3 \% \mathrm{~d}^{-1}$ or $0.13 \% \mathrm{dd}^{-1}$ ) in coarse-mesh litterbags (Fig. 1A) and $10 \%\left(0.5 \% \mathrm{~d}^{-1}\right.$ or $0.05 \%$ $\mathrm{dd}^{-1}$ ) in fine-mesh litterbags (Fig. 1B). In contrast, irradiation caused effects on litter stoichiometry, with differences among families for some variables. The $\mathrm{C}: \mathrm{N}$ ratio was higher in irradiated compared to control litter, regardless of the family, with increases of $32 \%$ and $8 \%$ on average in coarse-mesh and fine-mesh litterbags, respectively (Fig. 1C, D). Similarly, the C:P ratio increased with irradiation (104\% and $25 \%$ on average for coarse-mesh and fine-mesh litterbags, respectively), but the change differed across families, being greatest for Moraceae (Fig. 1E, F). The N:P ratio also increased with irradiation $(62 \%$ and $13 \%$ on average for coarse-mesh and fine-mesh litterbags, respectively). There were differences in the N:P ratio among families in coarse-mesh litterbags, with Betulaceae showing the greatest contrast (Fig. 1G, H).

There were no differences between irradiated and control litter in invertebrate abundance, detritivore abundance, detritivore richness, or among plant families (Fig. 2A, B, D), but invertebrate richness was $29 \%$ higher in control than in irradiated litter on average (Table 2; Fig. 2C). Thirty-six invertebrate taxa, including 13 litter-consuming detritivores, were found within coarse-mesh litterbags at the end of the experiment (Table S1).

\section{Discussion}

Our results provided evidence of gamma irradiation effects on leaf litter stoichiometry after 3 weeks of
Table 1 Results of linear mixed-effects models examining differences in instream decomposition (proportion of litter mass loss) and carbon (C), nitrogen $(\mathrm{N})$, and phosphorus $(\mathrm{P})$ ratios between control and irradiated leaf litter incubated in coarse-mesh and fine-mesh litterbags

\begin{tabular}{|c|c|c|c|c|c|c|}
\hline \multirow[t]{2}{*}{ Effect } & \multicolumn{3}{|c|}{ Coarse mesh } & \multicolumn{3}{|c|}{ Fine mesh } \\
\hline & $d f$ & $F$ & $P$ & $d f$ & $F$ & $P$ \\
\hline \multicolumn{7}{|l|}{ Decomposition } \\
\hline Irradiation & 1.42 & 3.05 & 0.088 & 1.42 & 0.08 & 0.785 \\
\hline Plant family & 2.6 & 3.74 & 0.088 & 2.6 & 0.46 & 0.655 \\
\hline Irradiation $*$ plant family & 2.42 & 1.02 & 0.368 & 2.42 & 0.20 & 0.816 \\
\hline \multicolumn{7}{|l|}{$\mathrm{C}: \mathrm{N}$ ratio } \\
\hline Irradiation & 1.37 & 12.31 & 0.001 & 1.42 & 9.06 & 0.004 \\
\hline Plant family & 2.6 & 19.60 & 0.002 & 2.6 & 82.85 & $<0.001$ \\
\hline Irradiation * plant family & 2.37 & 2.95 & 0.065 & 2.42 & 0.95 & 0.395 \\
\hline \multicolumn{7}{|l|}{$\mathrm{C}: \mathrm{P}$ ratio } \\
\hline Irradiation & 1.37 & 140.13 & $<0.001$ & 1.42 & 36.99 & $<0.001$ \\
\hline Plant family & 2.6 & 6.57 & 0.031 & 2.6 & 9.24 & 0.015 \\
\hline Irradiation * plant family & 2.37 & 7.65 & 0.002 & 2.42 & 1.88 & 0.165 \\
\hline \multicolumn{7}{|l|}{$\mathrm{N}: \mathrm{P}$ ratio } \\
\hline Irradiation & 1.37 & 90.18 & $<0.001$ & 1.42 & 10.27 & 0.003 \\
\hline Plant family & 2.6 & 11.75 & 0.008 & 2.6 & 17.10 & 0.003 \\
\hline Irradiation $*$ plant family & 2.37 & 7.75 & 0.002 & 2.42 & 1.45 & 0.246 \\
\hline
\end{tabular}



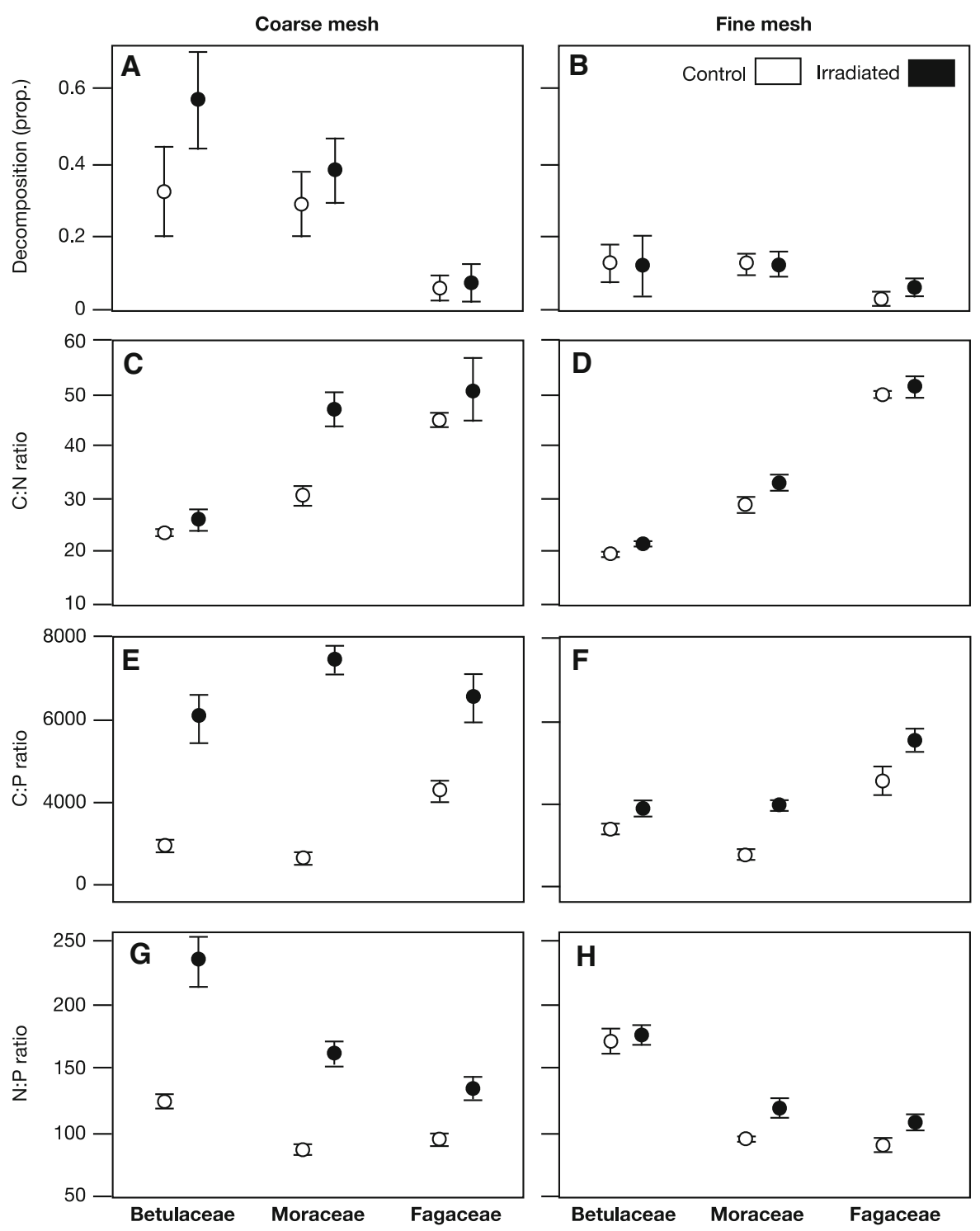

Fig. 1 Mean values \pm standard error of (A-B) instream decomposition (proportion of litter mass loss) and (C-H) carbon (C), nitrogen $(\mathrm{N})$, and phosphorus $(\mathrm{P})$ ratios in control and irradiated litter incubated in coarse-mesh and fine-mesh litterbags

instream incubation. The $\mathrm{C}: \mathrm{N}, \mathrm{C}: \mathrm{P}$, and $\mathrm{N}: \mathrm{P}$ ratios were greater in irradiated than in control litter, indicating greater losses of $\mathrm{N}$ and $\mathrm{P}$ (mostly $\mathrm{P}$ ) during or before instream incubation. Although we did not examine litter stoichiometry before incubation and, thus, cannot know exactly when nutrient losses occurred, it is probable that they occurred in the water. Other studies have found that changes in soil structure induced by gamma irradiation are greater in wet than in dry material (Howard \& Frankland, 1974), and that wet litter is more prone to freezing effects resulting from increased leaching and reduced microbial decomposition (Correa-Araneda et al., 2020; Pérez et al., 2021). Our finding of no difference in decomposition rates between irradiated and control litter suggests that the loss of nutrients occurred over a longer timeframe than leaching (see below).

Despite the changes in litter stoichiometry, we found no effects of gamma irradiation on total or microbial rates of litter decomposition during our 3-week instream incubation. Moreover, the number of invertebrates colonizing litter at the end of the 

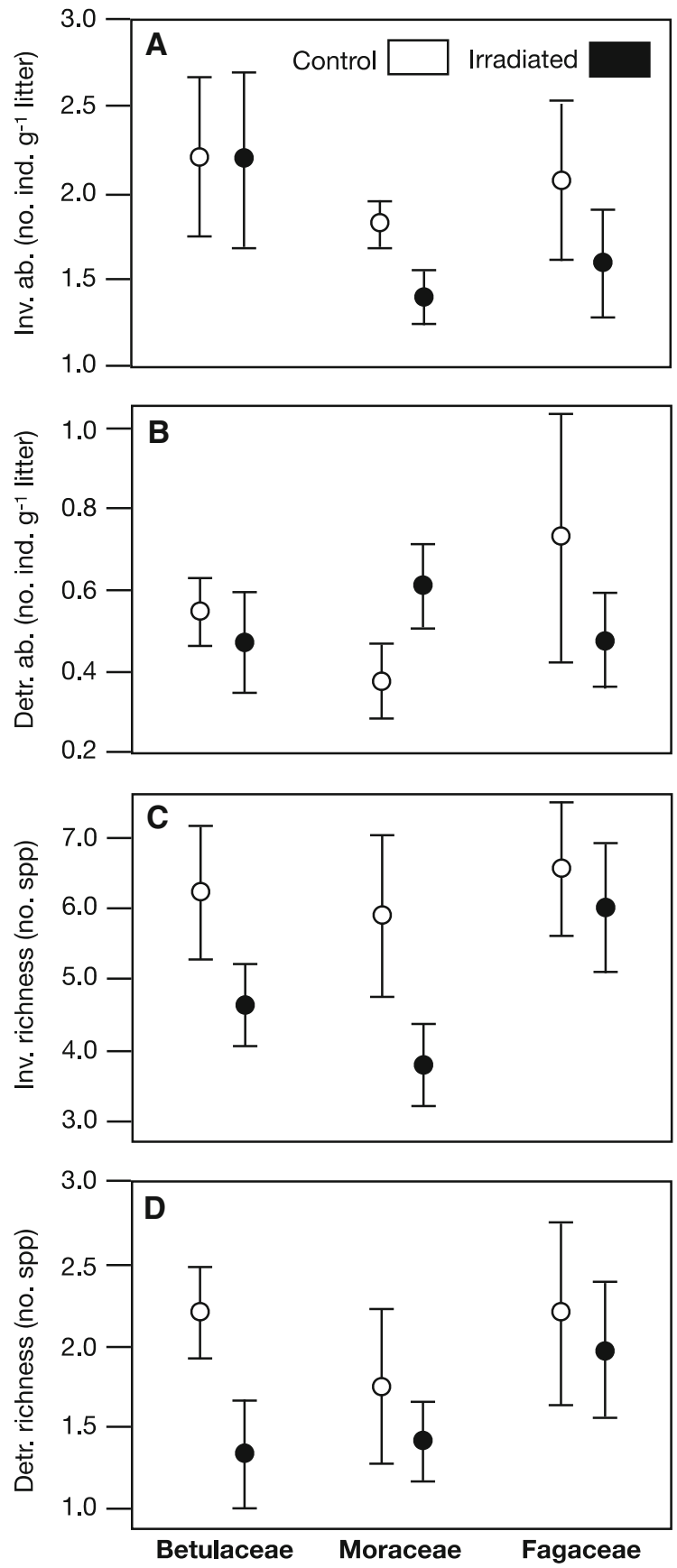

Fig. 2 Mean values \pm standard error of $(A, B)$ abundance (number of individuals per $\mathrm{g}$ of litter) and $(\mathrm{C}, \mathrm{D})$ taxonomic richness (number of taxa per litterbag) of $(\mathrm{A}, \mathrm{C})$ invertebrates and $(\mathrm{B}, \mathrm{D})$ detritivores in control and irradiated leaf litter incubated in coarse-mesh litterbags

experiment did not differ, although there were more taxa on average in the control than in the irradiated litter. The lack of effect on decomposition could be
Table 2 Results of linear mixed-effects models examining differences in the abundance (number of individuals per $g$ of leaf litter) and taxonomic richness (number of taxa per litterbag) of invertebrates and detritivores between control and irradiated leaf litter incubated in coarse-mesh litterbags

\begin{tabular}{lrll}
\hline Effect & $d f$ & $F$ & $P$ \\
\hline Invertebrate abundance & & & \\
$\quad$ Irradiation & 41 & 1.26 & 0.269 \\
$\quad$ Plant family & 6 & 0.94 & 0.440 \\
$\quad$ Irradiation * plant family & 41 & 0.21 & 0.808 \\
Invertebrate richness & & & \\
$\quad$ Irradiation & 41 & 4.56 & 0.039 \\
$\quad$ Plant family & 6 & 1.06 & 0.404 \\
$\quad$ Irradiation * plant family & 41 & 0.48 & 0.624 \\
Detritivore abundance & & & \\
$\quad$ Irradiation & 41 & 0.04 & 0.833 \\
Plant family & 6 & 0.10 & 0.904 \\
Irradiation * plant family & 41 & 1.25 & 0.297 \\
Detritivore richness & & & \\
Irradiation & 41 & 2.25 & 0.141 \\
Plant family & 6 & 0.47 & 0.647 \\
Irradiation * plant family & 41 & 0.38 & 0.685 \\
\hline Numerator &
\end{tabular}

Numerator degrees of freedom for different factors are the same to all fitted models: irradiation (1), plant family (2), and their interaction (2)

partly due to the duration of the experiment, as there was an apparent trend for irradiated litter of Betulaceae and Moraceae (but not Fagaceae) to decompose more than control litter in coarse-mesh litterbags (Fig. 1A), but the trend was not supported statistically. Further studies are needed to determine longer-term effects of gamma irradiation on decomposition rates.

Most studies assessing the effects of gamma irradiation have been conducted using living plants, soils, or fruits of commercial interest (e.g., Mostafidi et al., 2020; Gorman et al., 2021). Evidence for leaf litter is scarce and has suggested weak effects (e.g., Howard \& Frankland, 1974), but some studies have avoided litter sterilization to prevent potentially larger effects on litter chemistry (Seena et al., 2019). However, many experimental studies have sterilized litter using gamma irradiation with no consideration of potential effects. In some cases, all the litter material used in experiments is irradiated, eliminating any confounding effects, although the possible influence 
of irradiation on the results is not discussed (e.g., Gulis \& Suberkropp, 2003; Matulich \& Martiny, 2015). In other cases, irradiated and non-irradiated litter is not differentiated in analyses, which may confound the experimental results (e.g., Veen et al., 2019). Other studies have used autoclaving for litter sterilization, reporting that it promotes initial leaching (e.g., Ferreira \& Chauvet, 2011; Landeira-Dabarca et al., 2019). Gamma irradiation is generally considered less aggressive than other sterilization methods (McNamara et al., 2003; Berns et al., 2008), hence its wide use in agriculture (Zarbakhsh \& Rastegar, 2019), but its specific effects on litter physical structure and chemistry are still not well known.

A potential mechanism explaining the greater nutrient losses in irradiated litter found here is cell damage, as suggested for soil samples (McNamara et al., 2003). Notably, the effects of irradiation on plant cells and microorganisms depend on the dose and exposure time (Silindir \& Özer, 2009). While lower doses than that applied here might lead to weaker or no changes in the litter, they may not effectively remove all the microorganisms (Mostafidi et al., 2020), some of which (mostly endophytes) promote the subsequent colonization by aquatic hyphomycetes (Seena \& Monroy, 2016; Koivusaari et al., 2019). Similarly, chronic exposure to gamma irradiation accelerates litter decomposition and leaching in forests (Woodwell \& Marples, 1968; Saas \& Grauby, 1975), but effects may be lower and less consistent for acute exposure, as shown here.

\section{Conclusion}

We show that sterilization of various plant species with gamma irradiation can alter the stoichiometry of litter in streams, with nutrient losses occurring within the typical timespan (3 weeks) of instream litter decomposition experiments (Bärlocher, 2020). Conversely, we found no evidence of altered decomposition rates or colonization by litter-consuming detritivores in that timeframe. The lack of effects on decomposition could be partly due to the short duration of our experiment, so longer studies are recommended.

We suggest that gamma irradiation can be a useful procedure for litter sterilization in large-scale studies involving multiple countries, as long as decomposition rate is the main response variable (Boyero et al., 2011, 2021c). However, studies involving litter stoichiometry should control for any potential changes in litter chemistry caused by irradiation. Further studies are needed to explore the influence of different sterilization methods and irradiation doses on litter chemistry, so a common methodology can be established for large-scale studies where artificial substrates cannot be used.

Acknowledgements E. Chauvet, A. Encalada, M. Graça, B. McKie, C. M'Erimba, A. Ramírez, and C. Swan collected and provided litter. J. Pozo helped with fieldwork. A. Alonso helped with litter chemical analyses.

Author contributions All authors designed the study. AD and RGP organized the handling of the leaf litter in Australia. LB, NLR, and JP conducted the fieldwork and analyzed the data. NLR and JP processed the samples and did the litter chemical analyses. NLR sorted and identified the invertebrates. LB wrote the manuscript with substantial feedback from all other authors.

Funding Open Access funding provided thanks to the CRUECSIC agreement with Springer Nature. The study was funded by Basque Government funds (IT951- 16) to the UPV/EHU Stream Ecology Group.

Data availability The authors declare that they can make the data available.

Code availability Not applicable.

\section{Declarations}

Conflict of interest We declare no conflicts of interest or competing interests.

Ethical approval Not applicable.

Consent to participate Not applicable.

Consent for publication Not applicable.

Open Access This article is licensed under a Creative Commons Attribution 4.0 International License, which permits use, sharing, adaptation, distribution and reproduction in any medium or format, as long as you give appropriate credit to the original author(s) and the source, provide a link to the Creative Commons licence, and indicate if changes were made. The images or other third party material in this article are included in the article's Creative Commons licence, unless indicated otherwise in a credit line to the material. If material is not included in the article's Creative Commons licence and your intended use is not permitted by statutory regulation or exceeds the permitted use, you will need to obtain permission directly from the copyright holder. To view a copy of this licence, visit http://creativecommons.org/licenses/by/4.0/. 


\section{References}

APHA, 1998. Phosphorus: automated ascorbic acid reduction method, 4500-P, F. In Franson, M. A. H. (ed), Standard Methods for the Examination of Water and Wastewater, 20th edition. American Public Health Association, Washington, DC: $148-149$.

Bärlocher, F., 2020. Leaf mass loss estimated by litter bag technique. In Bärlocher, F., M. O. Gessner \& M. A. S. Graça (eds), Methods to Study Litter Decomposition: A Practical Guide Second Edition. Springer, Dordrecht: 43-52.

Berns, A. E., H. Philipp, H. D. Narres, P. Burauel, H. Vereecken \& W. Tappe, 2008. Effect of gamma-sterilization and autoclaving on soil organic matter structure as studied by solid state NMR, UV and fluorescence spectroscopy. European Journal of Soil Science 59: 540-550.

Bjelke, U., J. Boberg, J. Oliva, K. Tattersdill \& B. G. McKie, 2016. Dieback of riparian alder caused by the Phytophthora alnicomplex: Projected consequences for stream ecosystems. Freshwater Biology 61: 565-579.

Boyero, L. \& R. G. Pearson, 2017. Global-scale coordinated networks as a tool for exploring the functioning of stream ecosystems. Limnetica 36: 557-565.

Boyero, L., R. G. Pearson, M. O. Gessner, L. A. Barmuta, V. Ferreira, M. A. S. Graça, D. Dudgeon, A. J. Boulton, M. Callisto, E. Chauvet, J. E. Helson, A. Bruder, R. J. Albariño, C. M. Yule, M. Arunachalam, J. N. Davies, R. Figueroa, A. S. Flecker, A. Ramírez, R. G. Death, T. Iwata, J. M. Mathooko, C. Mathuriau, J. F. Gonçalves, M. Moretti, T. Jinggut, S. Lamothe, C. M'erimba, L. Ratnarajah, M. H. Schindler, J. Castela, L. M. Buria, A. Cornejo, V. D. Villanueva \& D. C. West, 2011. A global experiment suggests climate warming will not accelerate litter decomposition in streams but may reduce carbon sequestration. Ecology Letters 14: 289-294.

Boyero, L., M. O. Gessner, R. G. Pearson, E. Chauvet, J. Pérez, S. D. Tiegs, A. M. Tonin, F. Correa-Araneda, N. LópezRojo \& M. A. S. Graça, 2021a. Global patterns of plant litter decomposition in streams. In Swan, C. M., L. Boyero \& C. Canhoto (eds), The Ecology of Plant Litter Decomposition in Stream Ecosystems. Springer, New York: 51-71.

Boyero, L., N. López-Rojo, A. M. Tonin, J. Pérez, F. CorreaAraneda, R. G. Pearson, J. Bosch, R. J. Albariño, S. Anbalagan, L. A. Barmuta, A. Basaguren, F. J. Burdon, A. Caliman, M. Callisto, A. R. Calor, I. C. Campbell, B. J. Cardinale, J. J. Casas, A. M. Chará-Serna, E. Chauvet, S. Ciapała, C. Colón-Gaud, A. Cornejo, A. M. Davis, M. Degebrodt, E. S. Dias, M. E. Díaz, M. M. Douglas, A. C. Encalada, R. Figueroa, A. S. Flecker, T. Fleituch, E. A. García, G. García, P. E. García, M. O. Gessner, J. E. Gómez, S. Gómez, J. F. Gonçalves, M. A. S. Graça, D. C. Gwinn, R. O. Hall, N. Hamada, C. Hui, D. Imazawa, T. Iwata, S. K. Kariuki, A. Landeira-Dabarca, K. Laymon, M. Leal, R. Marchant, R. T. Martins, F. O. Masese, M. Maul, B. G. McKie, A. O. Medeiros, C. M. M. Erimba, J. A. Middleton, S. Monroy, T. Muotka, J. N. Negishi, A. Ramírez, J. S. Richardson, J. Rincón, J. Rubio-Ríos, G. M. dos Santos, R. Sarremejane, F. Sheldon, A. Sitati, N. S. D.
Tenkiano, S. D. Tiegs, J. R. Tolod, M. Venarsky, A. Watson \& C. M. Yule, 2021b. Impacts of detritivore diversity loss on instream decomposition are greatest in the tropics. Nature Communications 12: 3700.

Boyero, L., J. Pérez, N. López-Rojo, A. M. Tonin, F. CorreaAraneda, R. G. Pearson, J. Bosch, R. J. Albariño, S. Anbalagan, L. A. Barmuta, L. Beesley, F. J. Burdon, A. Caliman, M. Callisto, I. C. Campbell, B. J. Cardinale, J. J. Casas, A. M. Chará-Serna, S. Ciapała, E. Chauvet, C. Colón-Gaud, A. Cornejo, A. M. Davis, M. Degebrodt, E. S. Dias, M. E. Díaz, M. M. Douglas, A. Elosegi, A. C. Encalada, E. de Eyto, R. Figueroa, A. S. Flecker, T. Fleituch, A. Frainer, J. S. França, E. A. García, G. García, P. García, M. O. Gessner, P. S. Giller, J. E. Gómez, S. Gómez, J. F. Gonçalves, M. A. S. Graça, R. O. Hall, N. Hamada, L. U. Hepp, C. Hui, D. Imazawa, T. Iwata, E. S. A. Junior, S. Kariuki, A. Landeira-Dabarca, M. Leal, K. Lehosmaa, C. M'Erimba, R. Marchant, R. T. Martins, F. O. Masese, M. Camden, B. G. McKie, A. O. Medeiros, J. A. Middleton, T. Muotka, J. N. Negishi, J. Pozo, A. Ramírez, R. S. Rezende, J. S. Richardson, J. Rincón, J. Rubio-Ríos, C. Serrano, A. R. Shaffer, F. Sheldon, C. M. Swan, N. S. D. Tenkiano, S. D. Tiegs, J. R. Tolod, M. Vernasky, A. Watson, M. J. Yegon \& C. M. Yule, 2021c. Latitude dictates plant diversity effects on instream decomposition. Science Advances 7: eabe7860.

Correa-Araneda, F., A. M. Tonin, J. Pérez, K. Álvarez, N. López-Rojo, A. Díaz, C. Esse, F. Encina-Montoya, R. Figueroa, A. Cornejo \& L. Boyero, 2020. Extreme climate events can slow down litter breakdown in streams. Aquatic Sciences 82: 25.

Fanin, N., D. Lin, G. T. Freschet, A. D. Keiser, L. Augusto, D. A. Wardle \& G. F. C. Veen, 2021. Home-field advantage of litter decomposition: from the phyllosphere to the soil. New Phytologist 231: 1353-1358.

Ferreira, V. \& E. Chauvet, 2011. Synergistic effects of water temperature and dissolved nutrients on litter decomposition and associated fungi. Global Change Biology 17: 551-564.

Ferreira, V., L. Boyero, C. Calvo, F. Correa, R. Figueroa, J. F. Gonçalves, G. Goyenola, M. A. S. Graça, L. U. Hepp, S. Kariuki, A. López-Rodríguez, N. Mazzeo, C. M’Erimba, S. Monroy, A. Peil, J. Pozo, R. Rezende \& F. Teixeira-deMello, 2018. A global assessment of the effects of eucalyptus plantations on stream ecosystem functioning. Ecosystems 22: 629-642.

Gessner, M. O. \& E. Chauvet, 2002. A case for using litter breakdown to assess functional stream integrity. Ecological Applications 12: 498-510.

Gorman, D., G. Skrzypek, J. McLaughlin, D. Bearham \& M. A. Vanderklift, 2021. Gamma irradiation of common biological samples for stable carbon and nitrogen isotope and elemental analyses. Rapid Communications in Mass Spectrometry.

Gulis, V. \& K. Suberkropp, 2003. Effect of inorganic nutrients on relative contributions of fungi and bacteria to carbon flow from submerged decomposing leaf litter. Microbial Ecology 45: 11-19.

Handa, I. T., R. Aerts, F. Berendse, M. P. Berg, A. Bruder, O. Butenschoen, E. Chauvet, M. O. Gessner, J. Jabiol, M. Makkonen, B. G. McKie, B. Malmqvist, E. T. Peeters, S. 
Scheu, B. Schmid, J. van Ruijven, V. C. Vos \& S. Hättenschwiler, 2014. Consequences of biodiversity loss for litter decomposition across biomes. Nature 509: 218-221.

Howard, P. J. A. \& J. C. Frankland, 1974. Effects of certain full and partial sterilization treatments on leaf litter. Soil Biology and Biochemistry 6: 117-123.

Koivusaari, P., M. V. Tejesvi, M. Tolkkinen, A. Markkola, H. Mykrä \& A. M. Pirttilä, 2019. Fungi originating from tree leaves contribute to fungal diversity of litter in streams. Frontiers in Microbiology 10: 651.

Landeira-Dabarca, A., J. Pérez, M. A. Graça \& L. Boyero, 2019. Joint effects of temperature and litter quality on detritivoremediated breakdown in streams. Aquatic Sciences 81: $1-10$.

López-Rojo, N., J. Pérez, J. Pozo, A. Basaguren, U. ApodakaEtxebarria, F. Correa-Araneda \& L. Boyero, 2021. Shifts in key leaf litter traits can predict effects of plant diversity loss on decomposition in streams. Ecosystems 24: 185-196.

Matulich, K. L. \& J. B. H. Martiny, 2015. Microbial composition alters the response of litter decomposition to environmental change. Ecology 96: 154-163.

McNamara, N. P., H. I. J. Black, N. A. Beresford \& N. R. Parekh, 2003. Effects of acute gamma irradiation on chemical, physical and biological properties of soils. Applied Soil Ecology 24: 117-132.

Mostafidi, M., M. R. Sanjabi, F. Shirkhan \& M. T. Zahedi, 2020. A review of recent trends in the development of the microbial safety of fruits and vegetables. Trends in Food Science \& Technology 103: 321-332.

Pérez, J., F. Correa-Araneda, N. López-Rojo, A. Basaguren \& L. Boyero, 2021. Extreme temperature events alter stream ecosystem functioning. Ecological Indicators 121: 106984.

Pinheiro, J. C., D. M. Bates, S. DebRoy, D. Sarkar \& R. C. Team, 2020. NLME: Linear and Nonlinear Mixed Effects Models. R package version 3.1-151. CRAN.Rproject.org/package=nlme.

R Core Team, 2020. R: A language and environment for statistical computing. $\mathrm{R}$ Foundation for Statistical Computing.

Saas, A. \& A. Grauby, 1975. The effect of chronic gamma irradiation on decay of oak (Quercus pubescens Willd) and dogwood (Cornus mas L.) leaves and subjacent litter. Radiation Botany 15: 141-151.

Seena, S. \& S. Monroy, 2016. Preliminary insights into the evolutionary relationships of aquatic hyphomycetes and endophytic fungi. Fungal Ecology 19: 128-134.

Seena, S., F. Bärlocher, O. Sobral, M. O. Gessner, D. Dudgeon, B. G. McKie, E. Chauvet, L. Boyero, V. Ferreira, A. Frainer, A. Bruder, C. D. Matthaei, S. Fenoglio, K. R. Sridhar, R. J. Albarino, M. M. Douglas, A. C. Encalada, E. Garcia, S. D. Ghate, D. P. Giling, V. Goncalves, T. Iwata, A. Landeira-Dabarca, D. McMaster, A. O. Medeiros, J. Naggea, J. Pozo, P. M. Raposeiro, C. M. Swan, N. S. D. Tenkiano, C. M. Yule \& M. A. S. Graça, 2019. Biodiversity of leaf litter fungi in streams along a latitudinal gradient. Science of the Total Environment 661: 306-315.

Silindir, M. \& A. Y. Özer, 2009. Sterilization methods and the comparison of e-beam sterilization with gamma radiation sterilization FABAD Journal of Pharmaceutical Sciences 34: 43-53.

Suberkropp, K., T. L. Arsuffi \& J. P. Anderson, 1983. Comparison of degradative ability, enzymatic activity, and palatability of aquatic hyphomycetes grown on leaf litter. Applied and Environmental Microbiology 46: 237-244.

Tachet, H., M. Bournaud, P. Richoux \& P. Usseglio-Polatera, 2000. Invertébrés d'eau douce: Systématique, biologie, écologie. CNRS éditions, Paris.

Tiegs, S. D. \& D. M. Costello \& M. W. Isken \& G. Woodward \& P. B. McIntyre \& M. O. Gessner \& E. Chauvet \& N. A. Griffiths \& A. S. Flecker \& V. Acuña \& R. Albariño \& D. C. Allen \& C. Alonso \& P. Andino \& C. Arango \& J. Aroviita \& M. V. M. Barbosa \& L. A. Barmuta \& C. V. Baxter \& T. D. C. Bell \& B. Bellinger \& L. Boyero \& L. E. Brown \& A. Bruder \& D. A. Bruesewitz \& F. J. Burdon \& M. Callisto \& C. Canhoto \& K. A. Capps \& M. M. Castillo \& J. Clapcott \& F. Colas \& C. Colón-Gaud \& J. Cornut \& V. Crespo-Pérez \& W. F. Cross \& J. M. Culp \& M. Danger \& O. Dangles \& E. de Eyto \& A. M. Derry \& V. D. Villanueva \& M. M. Douglas \& A. Elosegi \& A. C. Encalada \& S. Entrekin \& R. Espinosa \& D. Ethaiya \& V. Ferreira \& C. Ferriol \& K. M. Flanagan \& T. Fleituch \& J. J. Follstad Shah \& A. Frainer \& N. Friberg \& P. C. Frost \& E. A. Garcia \& L. García Lago \& P. E. García Soto \& S. Ghate \& D. P. Giling \& A. Gilmer \& J. F. Gonçalves \& R. K. Gonzales \& M. A. S. Graça \& M. Grace \& H.-P. Grossart \& F. Guérold \& V. Gulis \& L. U. Hepp \& S. Higgins \& T. Hishi \& J. Huddart \& J. Hudson \& S. Imberger \& C. Iñiguez-Armijos \& T. Iwata \& D. J. Janetski \& E. Jennings \& A. E. Kirkwood \& A. A. Koning \& S. Kosten \& K. A. Kuehn \& H. Laudon \& P. R. Leavitt \& A. L. Lemes da Silva \& S. J. Leroux \& C. J. LeRoy \& P. J. Lisi \& R. MacKenzie \& A. M. Marcarelli \& F. O. Masese \& B. G. McKie \& A. Oliveira Medeiros \& K. Meissner \& M. Miliša \& S. Mishra \& Y. Miyake \& A. Moerke \& S. Mombrikotb \& R. Mooney \& T. Moulton \& T. Muotka \& J. N. Negishi \& V. Neres-Lima \& M. L. Nieminen \& J. Nimptsch \& J. Ondruch \& R. Paavola \& I. Pardo \& C. J. Patrick \& E. T. H. M. Peeters \& J. Pozo \& C. Pringle \& A. Prussian \& E. Quenta \& A. Quesada \& B. Reid \& J. S. Richardson \& A. Rigosi \& J. Rincón \& G. Rîşnoveanu \& C. T. Robinson \& L. Rodríguez-Gallego \& T. V. Royer \& J. A. Rusak \& A. C. Santamans \& G. B. Selmeczy \& G. Simiyu \& A. Skuja \& J. Smykla \& K. R. Sridhar \& R. Sponseller \& A. Stoler \& C. M. Swan \& D. Szlag \& F. Teixeira-de Mello \& J. D. Tonkin \& S. Uusheimo \& A. M. Veach \& S. Vilbaste \& L. B. M. Vought \& C.-P. Wang \& J. R. Webster \& P. B. Wilson \& S. Woelfl \& M. A. Xenopoulos \& A. G. Yates \& C. Yoshimura \& C. M. Yule \& Y. X. Zhang \& J. A. Zwart, 2019. Global patterns and drivers of ecosystem functioning in rivers and riparian zones. Science Advances 5: eaav0486.

Veen, G. F., B. L. Snoek, T. Bakx-Schotman, D. A. Wardle, W. H. Putten \& F. Wang, 2019. Relationships between fungal community composition in decomposing leaf litter and home-field advantage effects. Functional Ecology 33: 1524-1535.

von Schiller, D., V. Acuna, I. Aristi, M. Arroita, A. Basaguren, A. Bellin, L. Boyero, A. Butturini, A. Ginebreda, E. Kalogianni, A. Larranaga, B. Majone, A. Martinez, S. 
Monroy, I. Munoz, M. Paunovic, O. Pereda, M. Petrovic, J. Pozo, S. Rodriguez-Mozaz, D. Rivas, S. Sabater, F. Sabater, N. Skoulikidis, L. Solagaistua, L. Vardakas \& A. Elosegi, 2017. River ecosystem processes: A synthesis of approaches, criteria of use and sensitivity to environmental stressors. Science of the Total Environment 596-597: 465-480.

Woodward, G., M. O. Gessner, P. S. Giller, V. Gullis, H. Hladyz, A. Lecerf, B. Malmqvist, B. G. McKie, S. D. Tiegs, H. Cariss, M. Dobson, A. Elosegi, V. Ferreira, M. A. S. Graça, T. Fleituch, J. O. Lacoursière, M. Nistorescu, J. Pozo, G. Risnoveanu, M. Schindler, A. Vadineanu, L. M. Vought \& E. Chauvet, 2012. Continental-scale effects of nutrient pollution on stream ecosystem functioning. Science 336 : 1438-1440.
Woodwell, G. M. \& T. G. Marples, 1968. The influence of chronic gamma irradiation on production and decay of litter and humus in an oak-pine forest. Ecology 49: 456-465.

Zarbakhsh, S. \& S. Rastegar, 2019. Influence of postharvest gamma irradiation on the antioxidant system, microbial and shelf life quality of three cultivars of date fruits (Phoenix dactylifera L.). Scientia Horticulturae 247: 275-286.

Publisher's Note Springer Nature remains neutral with regard to jurisdictional claims in published maps and institutional affiliations. 